\title{
膀脱腫瘍早期診断に和ける経腹壁的超音波断層法の有用性について
}

\author{
浜松医大泌尿器科（主任：河辺 香月教授） \\ 麦谷 荘一鈴木 俊秀田島惇 \\ 藤枝市立志太総合病院泌尿器科（主任：金子佳雄博士）

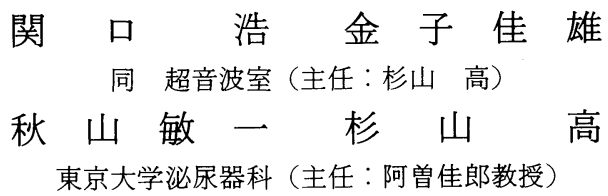 \\ 阿 兽 佳 郎
}

\section{THE VALUE OF TRANSABDOMINAL ULTRASONOGRAPHY IN EARLY DIAGNOSIS OF BLADDER TUMOR}

\author{
Soichi Mugiya, Toshihide Suzuki and Atsushi Tajima \\ Department of Urology, Hamamatsu University School of Medicine \\ (Chief: Prof. K. Kawabe) \\ Hiroshi Sekiguchi and Yoshio Kaneko \\ Department of Urology, Shida General Hospital \\ (Chief: Y. Kaneko, M.D.) \\ Toshikazu Akiyama and Ko Sugiyama \\ Laboratory of Ultrasonography, Shida General Hospital \\ (Chief: K. Sugiyama) \\ Yoshio Aso \\ Department of Urology, Faculty of Medicine, University of Tokyo \\ (Chairman: Prof. Y. Aso)
}

Ultrasonography is widely performed for screening of diseases in the upper abdomen. From April, 1985 to March, 1987, we carried out transabdominal ultrasonography of the entire abdomen for screening all the abdominal and pelvic diseases in the regular health check-up. Thirty-four cases out of 16,377 screened patients were ultrasonographically suspected of bladder tumor and received cystoscopic examination. Cystoscopy confirmed bladder tumors in 26 out of the 34 cases. Six among the 26 patients showed no urological symptoms and were seen as nonurological outpatients. Four of them revealed transitional cell carcinoma of low grade and low stage, while the rest of them transitional cell papilloma. The smallest tumor detected by ultrasonography was $3 \mathrm{~mm}$ in diameter.

Transabdominal ultrasonography of the entire abdominal organs proved useful for diagnosis of the bladder tumor at the early stage in the mass screening. Therefore, it is recommended to perform the lower abdominal scanning at the time of the ultrasonographical abdominal examination.

要旨：1985年 4 月より1987年 3 月までの 2 年間に, 藤枝市立志太総合病院において腹部疾患スクリーニ ングを目的として，腹部超音波断層法を計 16,377 人に施行した．下腹部経腹壁的走査もルーチン検査と

して実施したことにより，発見された無症候性膀朕腫瘍 6 例を対象として検討した。 6 例のらち 5 例は，泌尿器科以外の他科を受診して発見された。他の 1 例は，人間ドックの超音波断 層法により発見された. 全例とも尿路症状を認めず，6例のらち4 例は, 顕微鏡的血尿も認めなかった. いずれも早期膀胱癌, あるいは良性腫瘍であった。描出し得た最小の腫瘍径は $3 \mathrm{~mm}$ であった。 
経腹壁的超音波断層法は，膀胱腫瘍早期診断に有用であった。腹部疾患スクリーニングを目的とした 超音波断層法において，膀胱腫瘍早期診断のため，下腹部走査もルーチン検査として実施すべきである。

\section{1.はじめに}

近年，超音波断層装置の進歩に伴い，超音波断層法 によるスクリーニング検査が，各科領域で施行される よらになった。泌尿器科領域では, 渡辺らの経直腸的 超音波断層法を用いた前立腺集団検診が知られてい る。しかし現在広く一般に実施されている方法は，経 腹壁的超音波断層法である。これは特別な装置を必要 とせず，また非侵襲的で容易に施行できることより， 腹部疾患のスクリーニング検査法としては，現在最も 普及し繁用されている。

藤枝市立志太総合病院では, 腹部疾患のスクリーニ ングを目的として経腹壁的超音波断層法を用いてきた が2)3，1985年 4 月より，新たに下腹部走査をルーチン 検查として加え実施してきた。その結果，無症候性膀 胱腫瘍 6 例を発見した。 この事実に基ずき，膀脱腫瘍 早期診断に打ける経腹壁的超音波断層法の有用性につ いて検討したので，以下に報告する。

\section{2. 対象书よび方法}

1985年 4 月より 1987年 3 月までの 2 年間に，藤枝市 立志太総合病院を受診した外来，入院患者，および人 間ドック受診者を含め計 16,377 人に腹部超音波断層法 を施行した。その結果，膀胼腫瘍を疑われたものは34 例であった。このうち膀胱鏡で腫場が確認されたもの は26例（泌尿器科患者 20 例, 他科患者 5 例, 人間ドッ ク受診者 1 例）であった。今回はその中で，泌尿器科 以外の他科疾患として経過観察中に発見された 5 例 と, 人間ドック受診者 1 例を加えた計 6 例の膀胱腫瘍 症例を対象とした(表 1 )。これら 6 例のらち 4 例は移 行上皮癌， 2 例は移行上皮乳頭腫であった。組織学的 所見は膀胱癌取扱い規約に従って記載した4)。なお今
回の検討では，膀胱鏡であらかじめ腫瘍が確認されて いた症例や，膀脱腫瘍を疑い超音波断層法を施行した 症例は, 対象から除外した。

腹部超音波断層法では被検者全例に肝，胆道，膵， 脾，腎および膀脱，子宮，前立腺等の骨盤内葴器の観 察もルーチン検査として施行した ${ }^{5}$. 下腹部走查は, 被 検者の膀胱がある程度充満したところで経腹壁的に施 行した。使用した装置は, 東芝 SSA-90A，探触子は3.75 $\mathrm{MHz}$ のコンベックス型探触子を用いた。

\section{3. 症例}

症例 $1: 56$ 歳, 男性.

人間ドックにて肝機能異常を指摘され精查目的にて 内科を受診し，超音波断層法により膀胱腫瘍を指摘さ れた(図 1)，尿路症状はなく，顕微鏡的血尿もみられ なかった，膀胼鏡により，左尿管口下方に乳頭状，有 茎性腫瘍を認めた。同時に施行した CT では腫瘍は描 出されなかった．経尿道的腫瘍切除術 (TUR-Bt)を施 行した。摘出した腫瘍の大きさは $5 \times 5 \times 5 \mathrm{~mm}$ であっ た。組織学的診断は移行上皮癌 (TCC), 組織学的異型 度（grading）はG1であった。

症例 $2: 72$ 歳, 男性.

痛風のため内科入院中, 超音波断層法により膀脱腫 瘍を指摘された（図 2 )，尿路症状はなく，顕微鏡的血 尿もみられなかった。膀胼鏡により，膀胼䅡部 7 時の 部位に非乳頭状, 有茎性腫瘍を認め, TUR-Bt を施行 した. 腫瘍径は $3 \mathrm{~mm}$, 組織学的所見は TCC, G1であっ た.

症例 $3: 65$ 歳，男性.

人間ドックで娭查中に，超音波断層法により膀胖腫 瘍を指摘された。尿路症状はなく，顕微鏡的血尿もみ

表 1 超音波断層法にて発見された膀胀腫瘍

\begin{tabular}{|c|c|c|c|c|c|c|}
\hline 症例 & 年齢 & 性 & 主 & 腫瘍径 $(\mathrm{mm})$ & 顕微鏡的血尿 & 組織学的所見 \\
\hline 1 & 56 & M & 肝機能精查 & 5 & $(-)$ & TCC, G1 \\
\hline 2 & 72 & M & 痛風発作 & 3 & $(-)$ & TCC, G1 \\
\hline 3 & 65 & M & 人間ドック受診 & 7 & $(-)$ & TCC, G1 \\
\hline 4 & 31 & M & $\begin{array}{c}\text { 十二指腸潰瘍 } \\
\text { follow }\end{array}$ & 13 & $(-)$ & 移行上皮乳頭腫 \\
\hline 5 & 70 & M & 肺癌 follow & 15 & $(+)$ & TCC, G1 \\
\hline 6 & 42 & $\mathrm{~F}$ & 子宮筋腫 follow & 10 & $(+)$ & 移行上皮乳頭腫 \\
\hline
\end{tabular}

TCC : 移行上皮癌

G1 grading 1 
図 1 症例 1 の超音波断層像
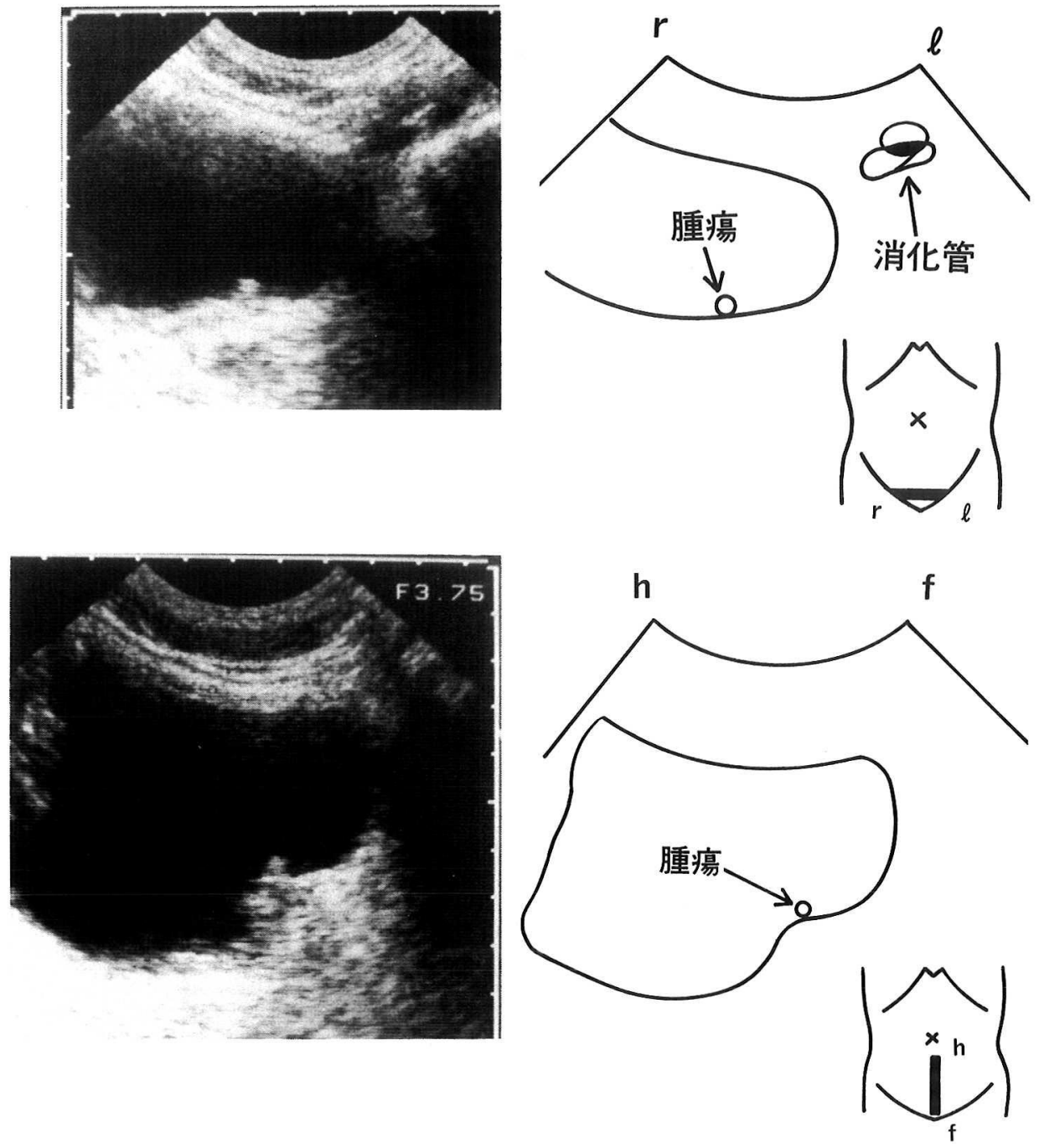

られなかった。膀胱鏡により，膀胱三角部右側に乳頭 状，有茥性腫瘍を認め，TUR-Bt を施行した。腫痬径 は7mm，組織学的所見はTCC，G1であった。

症例 $4: 31$ 歳, 男性.

十二指腸潰瘍のため内科において経過観察中，超音 波断層法により膀胱腫瘍を指摘された。尿路症状はな く，顕微鏡的血尿もみられなかった，膀胱鏡により， 後壁左尿管口内側に乳頭状, 有茎性腫瘍を認め, TURBt を施行した。腫瘍径は $13 \mathrm{~mm}$, 組織学的診断は移行 上皮乳頭腫であった。

症例 5:70歳, 男性.

肺癌 (腺癌) 術後 5 年を経て内科に扣いて経過観察

中，超音波断層法により膀胱腫瘍を指摘された。尿路 症状は認めなかったが，入院時の尿沈査では赤血球を 1 視野に数個認めた。膀胱鏡により後壁左尿管口上方 に乳頭状, 有茎性腫瘍を認め, TUR-Bt を施行した。 腫瘍径は $15 \mathrm{~mm}$, 組織学的所見は TCC, G1であった。

症例 $6: 42$ 歳, 女性.

子宮筋腫のため婦人科において経過観察中，超音波 断層法により膀胱腫瘍を指摘された。尿路症状は認め なかったが，入院時の尿沈査では赤血球を 1 視野に数 個認めた。膀胱鏡により後壁右尿管口上方に乳頭状, 有茎性腫瘍を認め, TUR-Bt を施行した。腫瘍径は10 $\mathrm{mm}$, 組織学的所見は移行上皮乳頭腫であった。 
図 2 症例 2 の超音波断層像
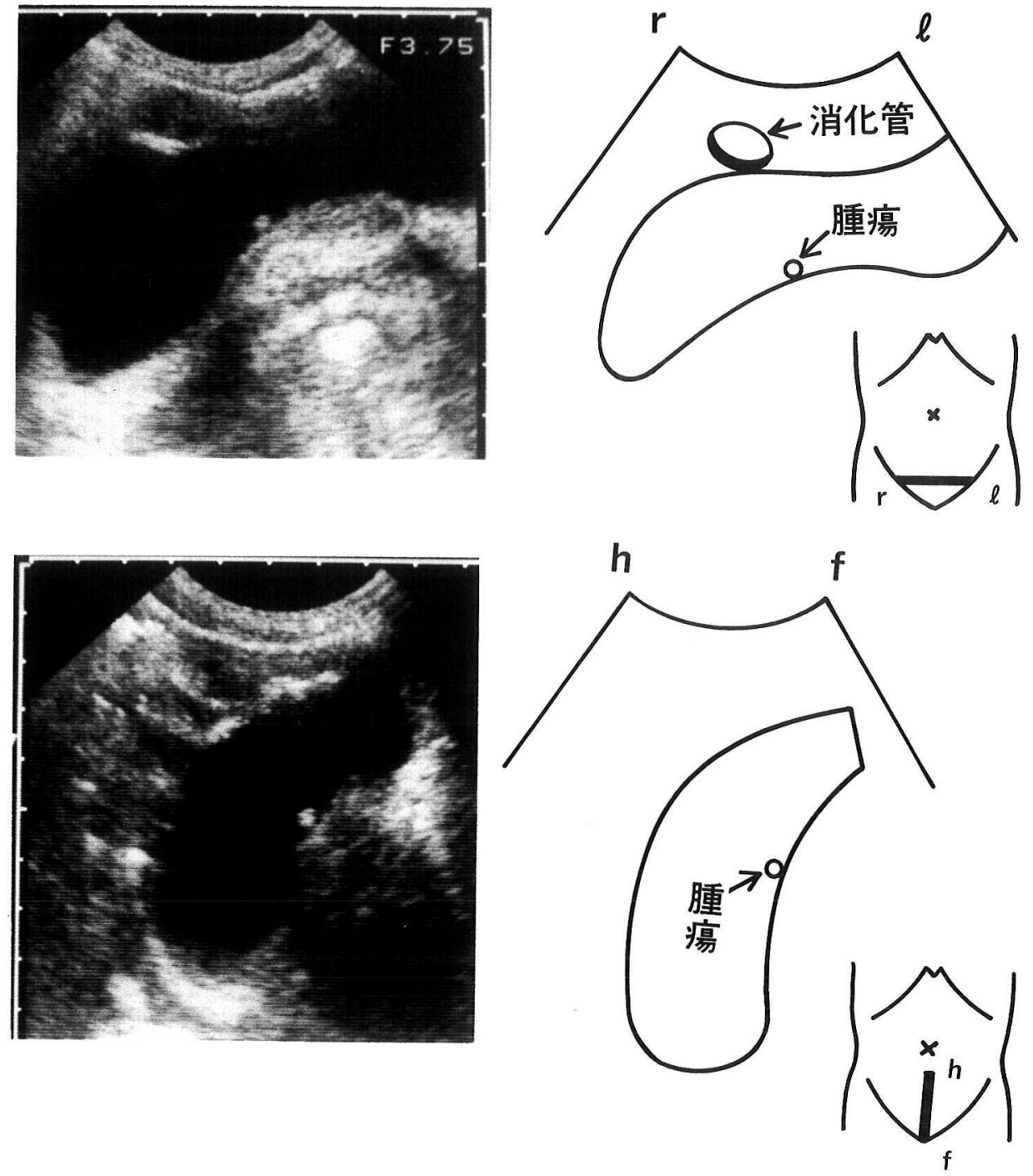

\section{4. 考 察}

1）超音波断層法の目的

従来, 膀胱腫瘍に括ける超音波断層法を施行する主

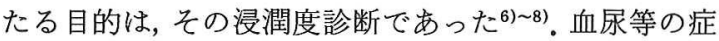
状で泌尿器科を受診し, 膀胱腫瘍が疑われると, 先ず 膀胼鏡検查が施行された。したがって膀胼腫瘍の有無 を，超音波断層法によって診断することはほとんどな かった。しかし最近の超音波断層装置の進歩や普及に 伴い, スクリーニング検査として積極的に用いられる ようになり，膀胱腫瘍の発見に有用であるという報告 が多数見られるよらになった ${ }^{9) \sim 11)}$.

\section{2) 方法}

現在, 超音波断層法に括ける膀胼の描出法としては, 経腹壁的, 経直腸的, 経尿道的断層法等がある。これ らの中でも経尿道的断層法は, 膀胖壁を広い範囲にわ たって明確に描出することが可能である6)。しかし経 尿道的, 経直腸的走查法は, 経腹壁的走查法に比し, 患者に与える苦痛が大きく，また専用装置を必要とす るため, スクリーニング検査法として適しているとは 言い難い。

一方、コンベックス型探触子の普及により経腹壁的 走査においても, 膀胱底部を中心とした広い範囲の観 
図 3 膀胱炎症例の超音波断層像
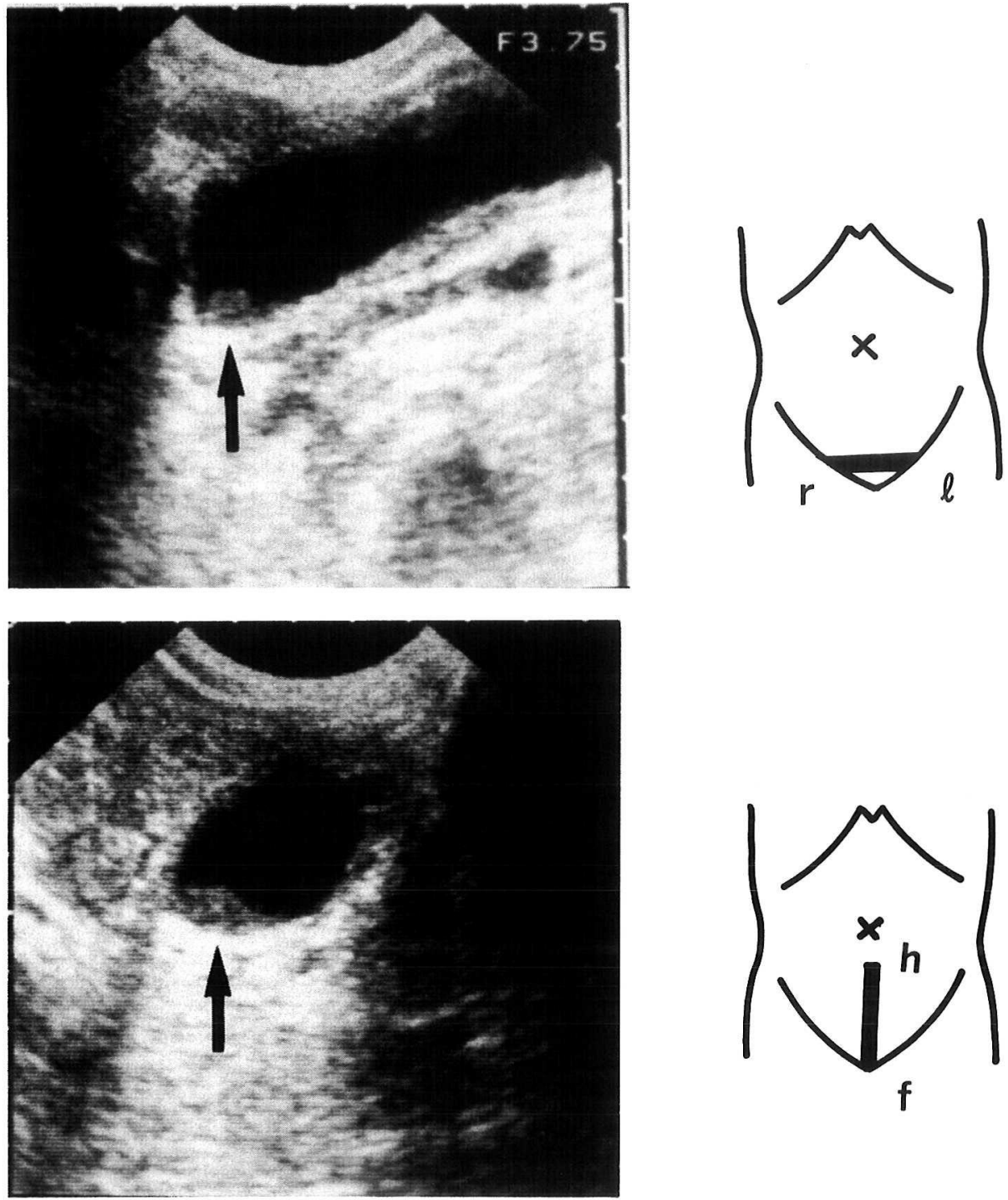

察が可能となった。また膀朕腫痬の浸潤度判定の適中 率に损いても，各走査法の間に有意差はなかったと報 告されている ${ }^{12)}$. 更に, 他の臟器と異なり膀胼の描出に 限定するならば, 膀胱がある程度尿で充満していれば, かなり信頼性の高い所見が得られる ${ }^{13)}$ 。

3) low grade, low stage の発見

ここに報告した 6 例の膀胱腫瘍はいずれも low grade, low stage の膀胱癌あるいは良性腫瘍であっ た。従来の如く，肉眼的血尿あるいは膀脂刺激症状等 を主訴として泌尿器科を受診し, 膀胱腫瘍の診断を受 けたものの中には, high grade, high stage の症例が
多く ${ }^{14115)}$, 予後が悪い症例があることを考えれば, 下腹 部超音波断層法の意義は，極めて高いものと考觉られ る.

4) false negative $と$ false positive

腫瘍が膀胱前壁あるいは頂部に存在する場合には， 診断が難しく，false negativeをきたす可能性がある ことに注意すべきである16).

なお今回の検討では, false positive は 8 例認められ た。全例とも膀脱炎による壁の浮腫状肥厚を描出した ものであった。超音波断層像では，いずれも膀胼壁の 不整な肥厚を認めた（図 3 )。腫瘍との鑑別は，膀胱鏡 
検査が不可欠な手段といえるが，超音波断層法による 経過観察によっても可能であるものと考えられた.

5）超音波断層法の有用性

膀胱鏡検查が膀胱腫瘍の診断に不可欠であることは いらまでもないが，顕微鏡的血尿を主訴とする患者全 例に，膀胱鏡検査を施行することは，必ずしも安全と は言い難い。現在，主に年齢や血尿の程度等を考えて 膀胱鏡検查の必要性が判断されることが多い。その際, 先ず非侵襲的である超音波断層法により腎, 膀胱の観 察を行い疑わしい症例に膀胱鏡検査を施行すれば，本 法の施行による膀脱腫瘍の早期診断の有用性は, 更に 高まるものと思われる。

\section{5。結 語}

1）腹部疾患スクリーニングを目的とした超音波断 層法に扣いて，無症候性膀胱腫瘍 6 例を発見したので 報告した。

2）経腹壁的超音波断層法は, 膀胱腫瘍早期診断に有 用であった。

3）腹部疾患スクリーニングを目的とした超音波断 層法において, 膀胱腫瘍早期診断のため, 下腹部走査 もルーチン検査として実施すべきである。

本論文の要旨は, 日本超音波医学会第49回研究発表会に 招いて発表した。

\section{文献}

1）渡辺 決, 大江 宏, 斎藤雅人, 板倉康啓, 中尾昌 宏：経直腸的超音波断層法を用いた前立腺集団検 診の現況．日泌尿会誌，76，913-920，1985。

2）麦谷荘一, 関口 浩, 金子佳雄, 秋山敏一, 杉山 高, 鈴木俊秀, 増田弘昭, 田島 惇, 阿曾佳郎：超 音波断層法により発見された腎細胞癌 25 症例の検 討。日泌尿会誌，78，1933-1939，1987。

3）麦谷荘一, 関口 浩, 金子佳雄, 秋山敏一, 杉山 高, 鈴木俊秀, 田島 惇, 阿曾佳郎：後腹膜腔及び 膀胱内病変スクリーニングに括ける腹部超音波断 層法の有用性について。日超医論文集，50，963 $-964,1987$.

4) 日本泌尿器科学会, 日本病理学会編：泌尿器科・病
理，膀胱癌取扱い規約。金原出版，東京，1980。

5）杉山 高, 秋山敏一, 綿野光浩, 中沢浩二, 脇 正 志, 渡辺文利: 腹部趣音波撮影法の検討。日超医論 文集，48，427-428，1986.

6）中村昌平：経尿道的超音波断層法の開発と膀胱一 の臨床応用。日泌尿会誌，72，511-529，1981。

7) 原田一哉, 狩野大陸, 棚橋善克, 渡辺 泱, 斎藤雅 人，三品輝夫：経直腸的超音波断層法に上る膀胱 診断。西日泌尿，39，33-37，1977。

8）白石哲郎：尿路疾患の超音波診断一膀胱腫瘍の浸 潤度判定に関する検討。日泌尿会誌，69，47-57, 1978 。

9）木津典久, 能登宏光, 鈴木隆志, 土田正義, 佐々木 秀平，高田 斉：経腹壁的超音波断層法を用いた 腎，膀胼，前立腺集団検診 (第 1 報)。日超医論文 集，48，847-848，1986。

10）森由実子，吉尾 晨，伊藤直人，本多正人，植原智 英子，森規左生：膀胱腫場スクリーニングにおけ る経腹壁的超音波検查の役割。日超医論文集，48， 861-862，1986。

11）大西克実, 板倉康啓, 渡辺 真, 川瀬義夫, 速水久 嗣, 中尾昌宏, 宮下浩明, 稲葉 正, 大江 宏, 渡 辺 泱：経直腸的超音波断層法を 1 次検診に用い た前立腺集団検診に执いて発見された膀胱腫瘍に ついて。超音波医学，14，42-45，1987。

12）小林徳郎，渡辺泱：超音波診断と CT 画像, (IV)骨盤，前立腺・膀胼。画像診断，5，645-652, 1985.

13) Itzchak, Y., Singer, D. and Fischelovitch, Y.: Ultrasonographic assessment of bladder tumors.I. Tumor detection. J. Urol., 126, 31-33, 1981.

14）高士宗久, 村瀬達良, 三宅弘治,三矢英輔：膀胼腫 瘍の統計学的検討一臨床的・病理学的因子々予後 との関係一. 日泌尿会誌, 76, 1323-1335, 1985.

15）松田 稔, 多田安温, 中野悦次, 藤岡秀樹, 高羽 津, 園田孝夫, 古武敏彦, 長船匡男 : 膀胱腫瘍の臨 床的研究。日泌尿会誌, 77, 208-219, , 1986 .

16）福井㦑：膀胱癌の早期診断。医学のあゆみ, 137, $733-737,1986$ 。

（1987年11月27日受理） 